ISSN $0258-7122$

Bangladesh J. Agril. Res. 32(3) : 413-420, September 2007

\title{
NUTRIENT UPTAKE AND YIELD OF ONION AS INFLUENCED BY NITROGEN AND SULPHUR FERTILIZATION
}

\author{
S. NASREen ${ }^{1}$, M. M. Haque ${ }^{2}$, M. A. Hossain ${ }^{3}$ \\ AND A. T. M. FARID
}

\begin{abstract}
The effect of nitrogen $(0,80,120$, and $160 \mathrm{~kg} / \mathrm{ha}$ from urea) and sulphur $(0,20$, 40 , and $60 \mathrm{~kg} / \mathrm{ha}$ from gypsum) fertilization on $\mathrm{N}$ and $\mathrm{S}$ uptake and yield performance of onion (var. BARI Piaz-1) was studied in the research field of Bangladesh Agricultural Research Institute (BARI), Joydebpur, Gazipur during rabi seasons of 2002-2003 and 2003-2004. The experiment was laid out in a randomized complete block design under factorial arrangement with three replications. Addition of nitrogen and sulphur fertilizers exerted significant influence on the number of leaves/plant, plant height, diameter of bulb, single bulb weight, and yield of onion. The uptake of $\mathrm{N}$ and $\mathrm{S}$ by bulb also significantly responded to the application of nitrogen and sulphur. The highest yield of onion and the maximum uptake of $\mathrm{N}$ and $\mathrm{S}$ were recorded by the combined application of $120 \mathrm{~kg} \mathrm{~N}$ and $40 \mathrm{~kg}$ S/ha with a blanket dose of $90 \mathrm{~kg}$ $\mathrm{P}_{2} \mathrm{O}_{5}, 90 \mathrm{~kg} \mathrm{~K} 2 \mathrm{O}$, and $5 \mathrm{~kg} \mathrm{Zn} /$ ha plus 5 tons of cowdung/ha. The antagonistic effect of nitrogen and sulphur on the uptake of $\mathrm{N}$ and $\mathrm{S}$ by bulb, yield components, and yield of onion was observed only when they were applied together at higher rates of nitrogen $(160 \mathrm{~kg} / \mathrm{ha})$ and sulphur $(40 \mathrm{~kg} / \mathrm{ha})$.
\end{abstract}

Key Words: Nutrient uptake, yield of onion, influenced and sulphur.

\section{Introduction}

Onion (Allium cepa L.) is one of most important crops among the spices in Bangladesh. It is used in almost all food preparation and is an integral part of Bangladesh diet (Hossain and Islam, 1994). It is grown extensively during winter season in Bangladesh, occupying the first position both in area (31, $6160 \mathrm{ha})$ and production $(27,2000 \mathrm{~m}$ tons) (BBS, 2005). It is grown in more or less in all the districts of the country, however, the average yield is $524 \mathrm{t} / \mathrm{ha}$, which is very low as compared to many other onion producing countries of the world. The average world production is about $15 \mathrm{t} / \mathrm{ha}$ (FAO, 1999). There is an acute shortage of onion in relation to is requirement. This necessiates an improvement of per hectare yield, which is possible through adoption of high yielding varieties and

${ }^{1}$ Principal Scientific Officer, Soil and Water Management Section, HRC, BARI Joydebpur, Gazipur, ${ }^{2}$ Scientific Officer, Spices Research Testing Station, Joydebpur, Gazipur, ${ }^{3}$ Principal Scientific Officer, On-Farm Research Division, Shyampur, Rajshahi, ${ }^{4}$ Director (SS), BARI, Joydebpur, Gazipur 1701, Bangladesh. 
judicious application of fetilizer. Concerning fertilizer application, nitrogen and sulphur are important since these two elements are highly deficient in this country's soils. Onion responded to $\mathrm{N}$ and $\mathrm{S}$ positively in terms of yield and quality of bulbs (Patel and Patel, 1990; Vachhani and Patel, 1993). Sulphur is essential for building up sulphur containing amino acids and also for a good vegetative growth and bulb development in onion (Anwar et al., 2001). Research information regarding the nitrogen and sulphur requirement for onion production in Bangladesh is insufficient or sporadic. In view of this, the present experiment was undertaken to assess the effect of different rates of nitrogen and sulphur fertilizers on the $\mathrm{N}$ and $\mathrm{S}$ uptake and yield performance of onion.

\section{Materials and Method}

A field experiment was conducted at the farm of the Bangladesh Agricultural Research Institute (BARI), Joydebpur, Gazipur during two consecutive rabi seasons of 2002-2003 and 2003-2004. The soil is silty clay loam belonging to Chhiata series of Grey Terrace soil (Aeric Albaquept). The initial soil samples collected from a depth of $20 \mathrm{~cm}$ were analyzed by ASI method (Hunter, 1984) and the properties are presented in Table 1 . The soil is slightly acidic in reaction (pH 6.0) with a low content of organic matter (1.05\%), total $\mathrm{N}(0.05 \%)$, available $\mathrm{P}(10 \mu \mathrm{g} / \mathrm{g}$, available S $(9 \mu \mathrm{g} / \mathrm{g})$ and exchangeable K $(0,18 \mathrm{meq} / 100 \mathrm{~g}$ soil $)$.

Four levels of nitrogen $(0,80,120$, and $160 \mathrm{~kg} \mathrm{~N} / \mathrm{ha}$ from urea) and four levels of sulphur $(0,20,40$, and $60 \mathrm{~kg} \mathrm{~S} / \mathrm{ha}$ from gypsum) were the treatment variables. The trial was set up in a randomized complete block design under factorial arrangement with three replications. A blanket dose of $90 \mathrm{~kg} \mathrm{P}_{2} \mathrm{O}_{5}, 90$ $\mathrm{K}_{2} \mathrm{O}$, and $5 \mathrm{~kg} \mathrm{Zn} / \mathrm{ha}$ were used in the form of triple superphosphate, muriate of potash, and zinc oxide, respectively. Cowdung at the rate of $5 \mathrm{t} / \mathrm{ha}$ was used in all the plots. Unit plot size was $3 \mathrm{~m} \times 4 \mathrm{~m}$. Full doses of gypsum, triple superphosphate, muriate of potash, zinc oxide, cowdung and $1 / 3^{\text {rd }}$ of urea were applied in the time of final land preparation. The remaining urea was top dressed in two equal instalments after third and sixth week of transplanting. The variety BARI Piaz-1 was used as a test crop. Forty-five day old seedlings were transplanted on 15 December in 2002 and 14 December in 2003 at a spacing of $20 \mathrm{~cm} \times 10 \mathrm{~cm}$. Mulching, weeding, and irrigation were done and plant protection measures were taken whenever required.

At maturity, five plants (i.e., bulbs) from each plot were collected randomly to determine dry matter accumulation. These samples were dried at $70^{\circ} \mathrm{C}$ in oven until a constant weight was attained. These dry bulbs were used for the estimation of $\mathrm{N}$ and $\mathrm{S}$ contents. Nitrogen content in bulb was determined by modified Kjeldahl digestion method (Yamakawa, 1993) and sulphur content was determined by ASI method (Hunter, 1984). Nitrogen and sulphur uptake was 
estimated as the dry matter multiplied by nitrogen and sulphur contents (\%). Another ten randomly selected plants were harvested from each plot to record the data on bulb diameter and bulb weight. The crop was harvested on 12 April in 2003 and 10 April in 2004. Bulb yield was recorded from an area of $6 \mathrm{~m}^{2}$ from each plot avoiding border effect. The data were then statistically analyzed and means were compared by using the least significant difference (LSD) test.

\section{Results and Discussion}

Yield attributes

Nitrogen had a significant effect on the yield attributes of onion in both the years (Table 1). Application of $120 \mathrm{~kg} \mathrm{~N} / \mathrm{ha}$ increased the number of leaves/plant and plant height significantly over the control as well as lower levels of nitrogen. Further increase in the level of nitrogen $(160 \mathrm{~kg} / \mathrm{ha})$ tended to decrease the number of leaves/plant and plant height. Nitrogen also influenced the size and weight of bulbs. There was significant increase in diameter and weight of bulbs due to application of nitrogen upto $120 \mathrm{~kg} / \mathrm{ha}$ and thereafter decreased. The size of bulb varied from 4.0 to $4.9 \mathrm{~cm}$ in 2002-2003 and 4.2 to $4.8 \mathrm{~cm}$ in 2003-2004 due to nitrogen application. The weight of bulb was increased by 24.1 and $33.6 \%$ in 2002-2003 and 25.4 and 41/7\% in 2003-2004 with 80 and $120 \mathrm{~kg} \mathrm{~N} / \mathrm{ha}$, respectively, over no nitrogen application. Sulphur fertilizer application also exerted significant influence on number of leaves/plant, plant height, bulb size, and weight of onion in both the years (Table 2). Plant height increased almost linearly with increasing $S$ reaching the maximum at $40 \mathrm{~kg} \mathrm{~S} / \mathrm{ha}$ and thereafter decreased. Application of sulphur increased the number of leaves/plant and was more with $40 \mathrm{~kg} \mathrm{~S} / \mathrm{ha}$ and lowest at $0 \mathrm{~kg} \mathrm{~S} / \mathrm{ha}$ in both the years. The diameter and weight of bulbs were significantly increased with the application of sulphur upto $40 \mathrm{~kg} / \mathrm{ha}$ and then decreased. However, weight of bulbs increased by 18.7 and $32.1 \%$ in 2002-2003 and 24.3 and $40.7 \%$ in 2003-2004 with 20 and $40 \mathrm{~kg} \mathrm{~S} / \mathrm{ha}$ as compared to without sulphur application. 


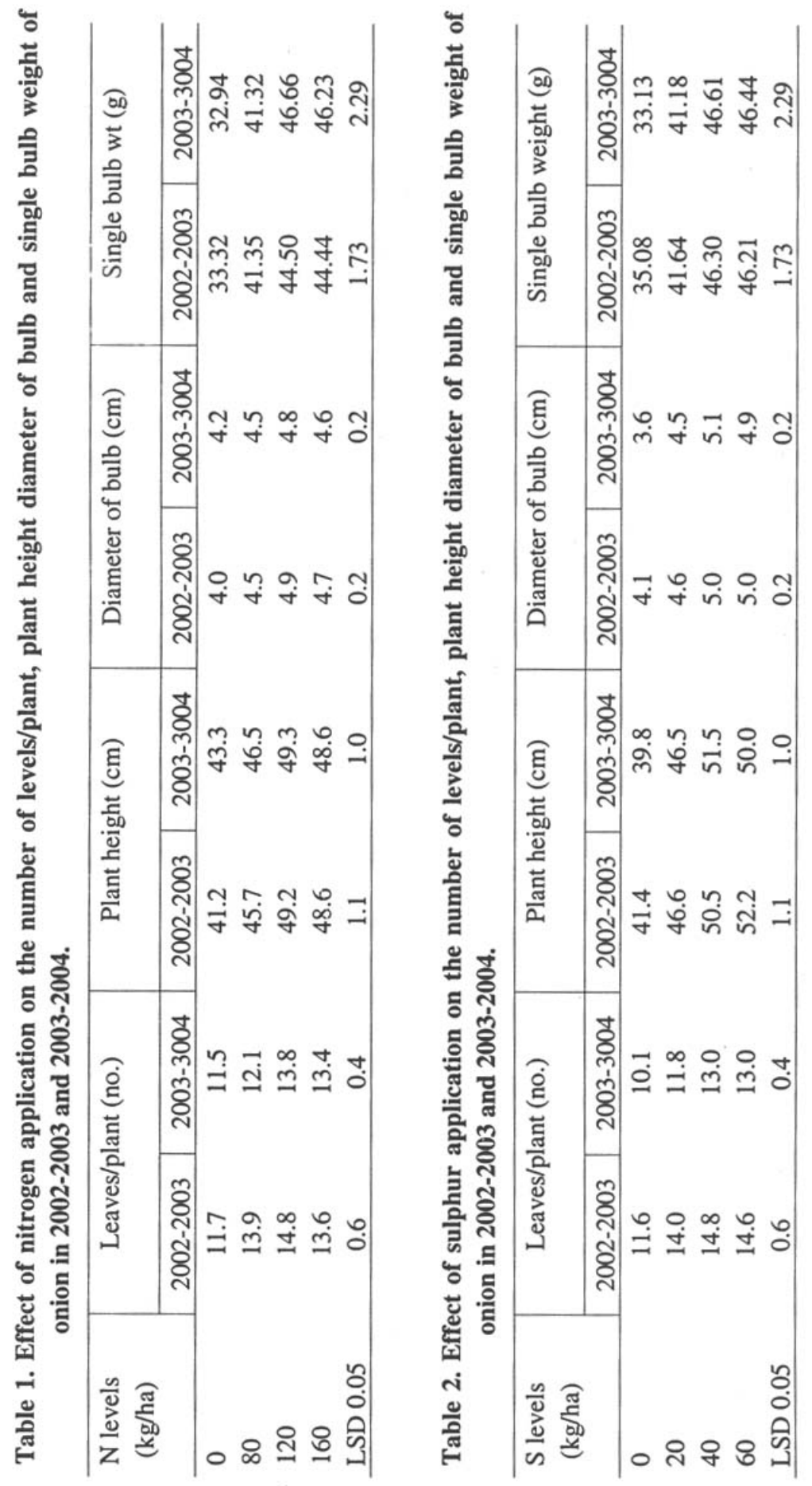




\section{Bulb yield}

Application of nitrogen fertilizer increased the bulb yield on onion significantly (Table 3). Increasing nitrogen levels from 0 to $120 \mathrm{~kg} / \mathrm{ha}$ resulted in progressive increase in bulb yield of onion. Similar result was also reported by Anwar et al. (2001) for onion. Further increase in nitrogen fertilizer $(160 \mathrm{~kg} / \mathrm{ha})$ tended to depress bulb yield. Plants grown without nitrogen fertilizer had the lowest bulb yield. The yield difference between the highest and the lowest yielding treatments was $62 \%$. Yield of onion was also significantly affected by the application of sulphur. It was observed that bulb yield was increased with successive increase in the levels of sulphur upto $40 \mathrm{~kg} / \mathrm{ha}$ and thereafter decreased. Application of $40 \mathrm{~kg}$ S/ha gave 70 and 20\% in 2002-2003 and 58 and 19.1\% in 2003-2004 higher bulb yield over no or $20 \mathrm{~kg} \mathrm{~S} / \mathrm{ha}$. Peterson (1979) also reported the increase in bulb yield with increase in sulphur level in onion and Singh et al. (1995) in garlic. It appears that there was a quantum jump in bulb yield due to fertilizer application suggesting that the soil was deficient in nitrogen and sulphur that resulted in a big yield differences even with $80 \mathrm{~kg} \mathrm{~N}$ or $20 \mathrm{~kg} \mathrm{~S} / \mathrm{ha}$ application. This yield increase was due to the increase in bulb size and weight. Plants grown without added sulphur produced consistently lowest bulb. This result thus suggested that sulphur deficiency has adverse effect on growth and yield of onion.

There was no significant interaction effect of nitrogen and sulphur for any of the characters under study except bulb yield in the years (Table 3). However, yield of onion varied from 6.60 to $17.18 \mathrm{t} / \mathrm{ha}$ in $2002-2003$ and 6.80 to $17.22 \mathrm{t} / \mathrm{ha}$ in 2003-2004 due to different nitrogen and sulphur levels. At every rate of sulphur application, onion responded to nitrogen upto $120 \mathrm{~kg} / \mathrm{ha}$. Thus combined application of nitrogen and sulphur upto $120 \mathrm{~kg} \mathrm{~N}$ and $40 \mathrm{~kg} \mathrm{~S} / \mathrm{ha}$ showed a significant synergistic effect on the bulb yield of onion in both years. Further addition of nitrogen $(160 \mathrm{~kg} / \mathrm{ha})$ and sulphur $(60 \mathrm{~kg} / \mathrm{ha})$ decreased the yield of onion. This might have an imbalance or antagonistic effect on plant nutrition that resulted in lower yield.

\section{$\mathrm{N}$ and $\mathrm{S}$ uptake}

The uptake of $\mathrm{N}$ by onion bulb varied significantly due to different doses of nitrogen application in both the years (Table 4). Uptake of $\mathrm{N}$ by onion bulb increased progressively with added $\mathrm{N}$ fertilizer upto $120 \mathrm{~kg} / \mathrm{ha}$ and there was a reduction in uptake with $160 \mathrm{~kg} \mathrm{~N} / \mathrm{ha}$. Significantly the lowest N uptake was noted in onion bulb with $0 \mathrm{~kg} \mathrm{~N} / \mathrm{ha}$. $\mathrm{N}$ uptake by onion bulb also differed significantly due to variation of sulphur levels. Uptake of $\mathrm{N}$ by bulbs varied 


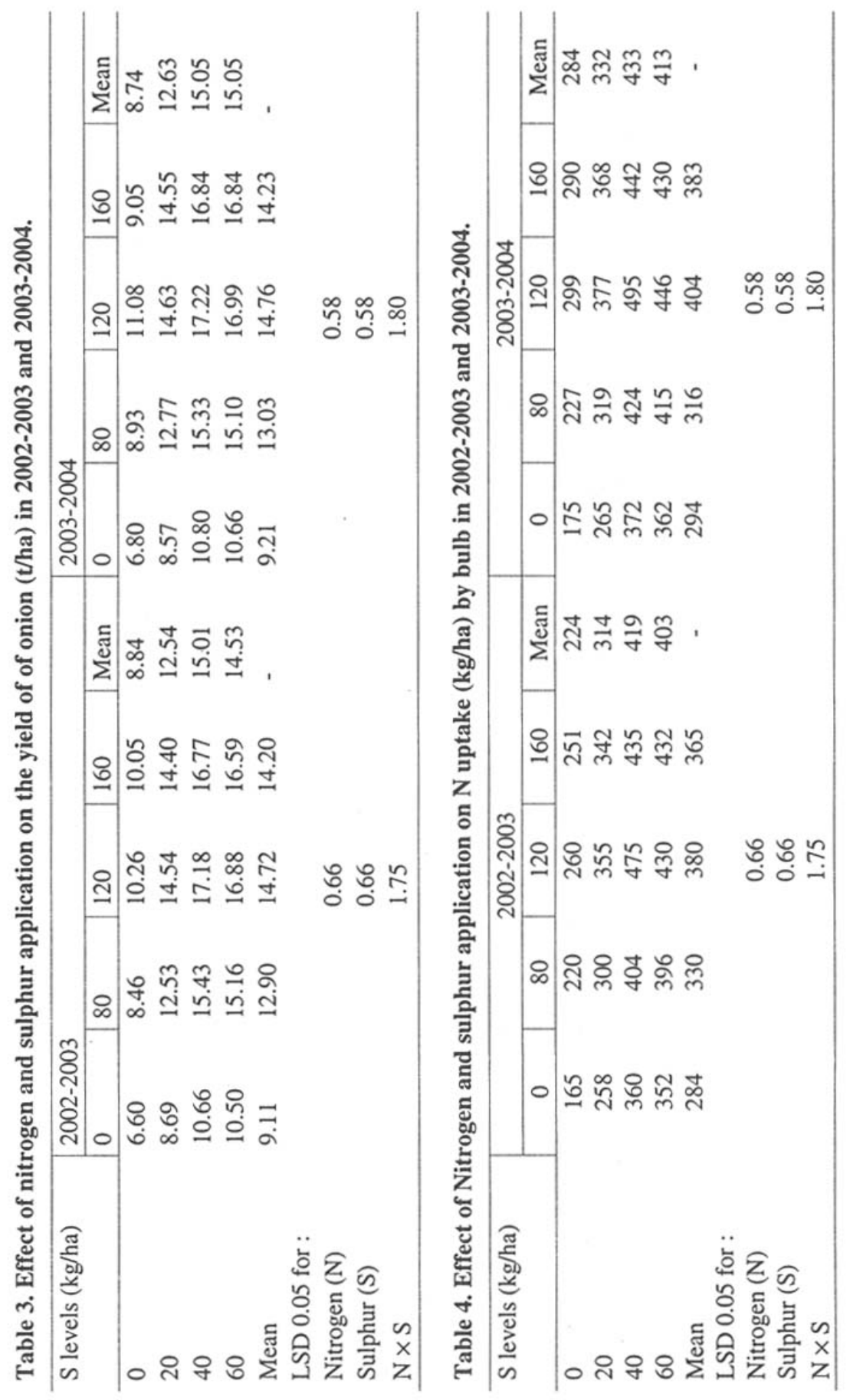




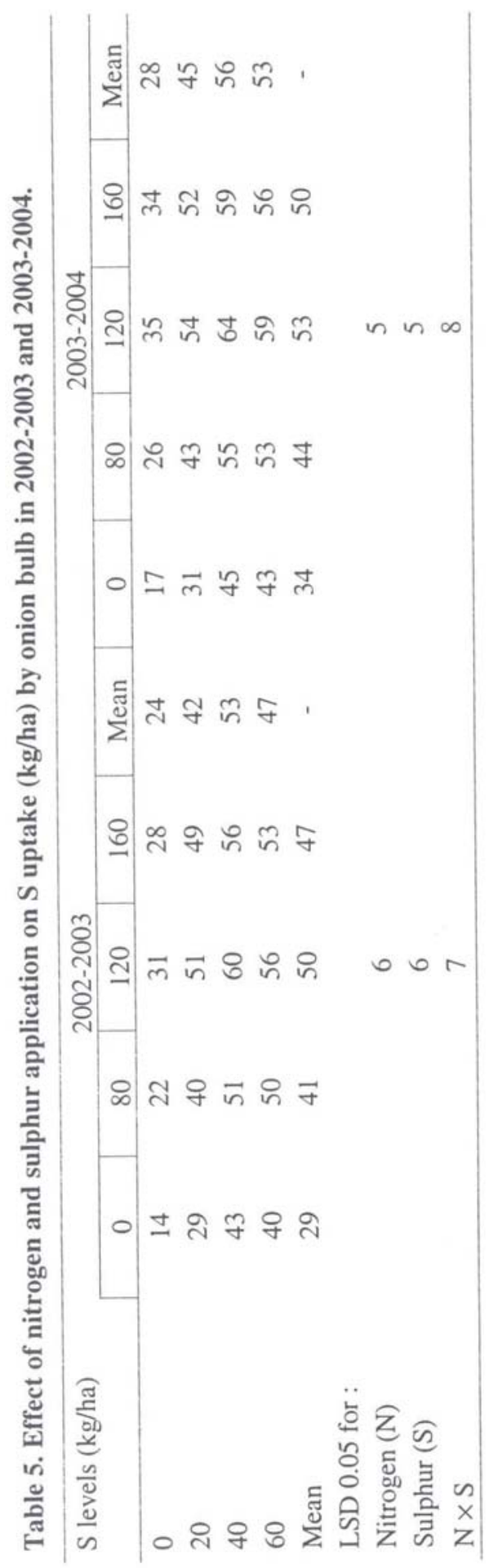


from 224 to $419 \mathrm{~kg} / \mathrm{ha}$ in $2002-2003$ and 248 to $433 \mathrm{~kg} / \mathrm{ha}$ in $2003-2004$ due to different sulphur levels. There was almost a liner increase in $\mathrm{N}$ uptake with the increased rate of sulphur application upto $40 \mathrm{~kg} / \mathrm{ha}$ and further increase in sulphur application decreased the $\mathrm{N}$ uptake. These results are in conformity with the findings of Singh et al. (1995). The interaction effect of nitrogen and sulphur on $\mathrm{N}$ uptake by the bulb was significant and the maximum value of $\mathrm{N}$ uptake was recorded with $120 \mathrm{~kg} \mathrm{~N} / \mathrm{ha}$ and $40 \mathrm{~kg} \mathrm{~S} / \mathrm{ha}$ (Table 4). The combined effect of nitrogen and sulphur on $\mathrm{N}$ uptake was found to be synergistic. Further increase of nitrogen $(160 \mathrm{~kg} / \mathrm{ha})$ and sulphur $(60 \mathrm{~kg} / \mathrm{ha})$ tended to decrease the $\mathrm{N}$ uptake by onion bulb. S uptake by onion bulb followed the pattern similar to that obtained for $\mathrm{N}$ uptake (Table 5). Fertilizer nitrogen and sulphur might have promoted the availability of native soil $\mathrm{N}$ and $\mathrm{S}$ as reflected by their uptake.

\section{Conclusion}

Application of $120 \mathrm{~kg} \mathrm{~N}$ and $40 \mathrm{~kg} \mathrm{~S} / \mathrm{ha}$ along with $90 \mathrm{~kg} \mathrm{P}_{2} \mathrm{O}_{5}, 90 \mathrm{~kg} \mathrm{~K}_{2} \mathrm{O}$ and 5 $\mathrm{kg} \mathrm{Zn/ha} \mathrm{plus} 5$ tons cowdung/ha might be an optimum combination for onion production in Grey Terrace Soil (Aeric Albaquept) Chhiata series (Agroecological zone-28) at Joydebpur, Gazipur.

\section{References}

Anwar, M. N., J. U. Sarker, M. Rahman, M.A. Islam and M. Begum. 2001. Response of onion to nitrogen, phosphorus, potassium, sulphur and zinc. Bangladesh J. Environ. Sci. 7: 68-72.

BBS (Bangladesh Bureau of Statistics). 2005. Statistical Poket Book of Bangladesh. Bangladesh Bureau of Statistics, Planning Division, Ministry of Planning, Govt. of the People's Republic of Bangladesh. p. 143.

FAO (Food and Agriculture Organization). 1999. FAO Quarterly bullentin of statistics. Food and Agriculture Organization of the United Nations, Rome Italy. 12:3-4.

Hossain, A.K.M. and J. Islam. 1994. Status of Allium cepa production in Bangladesh. Hort. Abst. 58:33-36.

Hunter, A. H. 1984. Soil Analytical Services in Bangladesh. BARI/Aids Consultancy Report. Contract Aid/388-005, Dhaka. Bangladesh. pp. 1-7.

Patel. I. J. and A. T. Patel. 1990. Effect of nitrogen and phosphorus levls on growth and yield of onion. (Allium cepa) cultivar Pusa Red Res. Gujarat Agric. Univ. 15: 1-5.

Peterson, O.R. 1979. Sulphur fertilizer effect on onion yield and pungency. Progress Report. Texas Agricultural experiment. Soil and Fert. Abst. 47 : 7935.

Singh. F., V. V. Singh and R. V. S. Mallik. 1995. Effect of different doses and sources of sulphur on yield and uptake of sulphur by garlic. J. Indan Soc. Soil Sci. 43:130-131.

Vachhani, M.U. and Z.O. Patel. 1993. Effect of nitrogen, phosphours and potash on bulb yield and quality of onion (Allium cepa). Indian J. Agron. 3: 333-334.

Yamakawa, T. 1993. Laboratory Methos for Soil Science Nutrition. Part-2. Methods of Analysis. JICA-IPSA Project. pp. 6-16. 